\title{
The Use of Milrinone in Patients with Delayed Cerebral Ischemia Following Subarachnoid Hemorrhage: A Systematic Review
}

\author{
Marcelo Lannes, Frederick Zeiler, Céline Guichon, Jeanne Teitelbaum
}

\begin{abstract}
Objective: The purpose of this article is to provide a systematic review of the evidence supporting the use of milrinone for the management of delayed cerebral ischemia (DCI) following subarachnoid hemorrhage (SAH). Design: Primary outcomes were functional neurological status and the incidence of cerebral infarction. Search strategies adapted to the different databases were developed by a professional librarian. Medline, EMBASE, the Cochrane Library database, Web of Science, SCOPUS, BIOSIS, Global Health, Health Star, Open SIGLE, Google Scholar and the New York Academy of Medicine Gray Literature were searched as well as clinical trials databases and the proceedings of several scientific meetings. Quality of the evidence for these outcomes across studies was adjudicated using the GRADE Working Group criteria. Results: The search resulted in 284 citations after elimination of duplicates. Of those 9 conference proceedings and 15 studies met inclusion criteria and consisted of case reports, case series and two comparative studies: one non-randomized study with physiological outcomes only and a case series with historical controls. There was considerable variation in dosing and in co-interventions and no case control or randomized controlled studies were found. Conclusion: There is currently only very low quality evidence to support the use of milrinone to improve important outcomes in patients with delayed cerebral ischemia secondary to subarachnoid hemorrhage. Further research is needed to clarify the value and risks of this medication in patients with SAH.
\end{abstract}

RÉSUMÉ: Utilisation de la milrinone chez les patients présentant de l'ischémie cérébrale retardée suite à une hémorragie sous-arachnoïdienne. Objectif: Le but de cet article est de présenter une revue systématique des données en faveur de l'utilisation de la milrinone dans le traitement de l'ischémie cérébrale retardée (ICR) suite à une hémorragie sous-arachnoïdienne (HSA). Méthodologie: L'état neurologique fonctionnel et l'incidence de l'infarctus cérébral étaient les critères d'évaluation primaires. Un bibliothécaire a élaboré des stratégies de recherche adaptées aux différentes bases de données. Nous avons mené des recherches dans les bases de données Medline, EMBASE, Cochrane Library, Web of Science, SCOPUS, Medicine Gray Literature ainsi que dans les bases de données portant sur les essais cliniques et les comptes rendus de réunions scientifiques. Nous avons déterminé la qualité des données concernant les résultats rapportés dans les différentes études au moyen des critères du GRADE Working Group. Résultats: Nous avons identifié 284 citations après avoir éliminé les publications redondantes. Parmi les publications retenues nous avons identifié 9 comptes rendus de réunions scientifiques et 15 études qui rencontraient les critères d'inclusion. Ces publications comportaient des études de cas et des séries de cas, et deux études comparatives : une étude non randomisée rapportant seulement l'impact physiologique du traitement et une série de cas avec témoins historiques. Il existait une variation considérable dans le dosage et les coïnterventions, et nous n'avons retrouvé aucune étude cas-témoin ou étude contrôlée et randomisée. Conclusion: Il existe actuellement seulement des données de très faible qualité à l'appui de l'utilisation de la milrinone pour améliorer l'issue d'une ischémie cérébrale retardée secondaire à une hémorragie sous-arachnoïdienne. Des études plus poussées devront être réalisées pour élucider quelle est l'efficacité et quels sont les risques que comporte cette médication chez les patients atteints d'une HSA.

Keywords: Cerebral vasospasm, subarachnoid hemorrhage, delayed ischemia milrinone doi:10.1017/cjn.2016.316

Can J Neurol Sci. 2017; 44: 152-160

\section{INTRODUCTION}

For patients who survive the initial episode of aneurysmal subarachnoid hemorrhage, clinical or symptomatic vasospasm, also known as delayed cerebral neurological deficit (DIND) occurs in $28.5 \%$, according to more recent series, ${ }^{1}$ and subsequent cerebral infarction correlates strongly with a poorer outcome. ${ }^{2}$ Indeed, the risk of death and disability from vasospasm remains a leading cause of poor outcome after $\mathrm{SAH}^{3}$

From the McGill University, Department of Anesthesiology, Montreal Neurological Hospital, Montreal, Canada (ML); Section of Neurosurgery, University of Manitoba, Winnipeg,

Manitoba, Canada (FZ); Department of Anesthesiology and Critical Care Medicine, Croix Rousse Hospital, Lyon, France (CG); McGill University, Department

of Neurology, Montreal Neurological Hospital, Montreal, Canada (JT).

Received February 16, 2016. Final Revisions Submitted June 6, 2016. Date of Acceptance June 20, 2016.

Correspondence to: Marcello Lanned, Department of Anesthesiology, Montreal Neurological Hospital, 3801 University St, room 548, Montreal, QC, H3A2B4

E-mail: Canadamarcelo.lannes@mcgill.ca. 
The pathogenesis of vasospasm remains poorly understood, and the various theories have been extensively reviewed in a recent article. ${ }^{4}$ Potential mechanisms include smooth muscle contraction that becomes chronic and inflammation that can lead to vessel remodeling. Milrinone is a phosphodiesterase (PDE) 3 inhibitor. PDEs, including PDE3, are present in cerebral smooth muscle $e^{3,4}$ and are involved in the regulation of smooth muscle function. Their inhibition leads to vasodilation by increasing the levels of intracellular cyclic adenosine monophosphate (cAMP). ${ }^{5}$ Milrinone's anti-inflammatory effects may inhibit the abnormal proliferation of the vascular smooth muscle and remodeling observed in patients with DCI through its effect on interleukin $6 .{ }^{6}$

Several centers in different countries have reported the use of milrinone in patients with SAH. A survey of 268 practitioners in neurocritical care from 172 institutions in 12 European countries revealed that already in 2012 milrinone was the second most common intra-arterial vasodilator agent used to treat symptomatic cerebral vasospasm. ${ }^{7}$ Despite its increasing use there has been no systematic review of the literature to help inform this practice. We thus undertook a systematic review to determine the quality of the existing evidence supporting the use of milrinone in the management of patients suffering from subarachnoid hemorrhage with the specific goal of preventing or treating delayed cerebral ischemia.

\section{MeTHODS}

This review was designed following the PRISMA statement for systematic reviews. ${ }^{8}$ A study protocol was written before developing the search strategies specifying the objectives and methods of this systematic review.

\section{Design and Search Strategy}

We conducted a systematic review of the pertinent literature without time or language limitations. The search was designed to retrieve publications on cerebral vasospasm and milrinone using a combination of relevant subject headings and text. A search strategy was initially developed and applied to Medline via OvidSP (1945 to April 27, 2016) with the assistance of a qualified librarian. This strategy was adapted to take into consideration the different characteristics of other databases: EMBASE via OvidSP (1974 to April 27, 2015), PubMed (only for records "as supplied by publisher"), the Cochrane Library (via Wiley), Web of Science, SCOPUS, and BIOSIS Previews via OvidSP (1969 to 2016 week 20). Searches were run on April 27, 2016 for all databases. Open SIGLE, Google Scholar, and the New York Academy of Medicine Gray Literature were used for the gray literature. References from review articles were scanned in an attempt to identify studies that could have been missed in the original search. The search was also extended to clinical trials databases (Clinicaltrials.gov, International Clinical Trials Registry Platform Search Portal). No limitation was placed on language or time. Furthermore we reviewed the proceedings for the past 5 years of the following scientific societies: The Canadian Neurological Sciences Federation (CNSF), the American Association of Neurological Surgeons (AANS), the Congress of Neurological Surgeons (CNS), the European Neurosurgical Society (ENSS), the World Federation of Neurological Surgeons (WFNS), the American Neurology Association (ANA), the American Academy of Neurology (AAN), the European Federation of Neurological Science (EFNS), the World Congress of Neurology (WCN), the Neurocritical Care Society, the European Society of Intensive Care
Medicine (ESICM), the Society of Critical Care Medicine (SCCM), and the annual Vasospasm Conference.

\section{Study Selection}

Following the study protocol we tried to identify any human study evaluating the efficacy of milrinone in patients with aneurysmal subarachnoid hemorrhage who were at risk of developing DCI or who were diagnosed with DCI. The search and the evaluation of potential studies were performed independently by three reviewers (ML, FZ and $\mathrm{CG}$ ); differences of opinion were resolved by discussion and consensus. We included studies that used amrinone, a bipyridine with PDE 3 inhibition properties that is very similar to milrinone.

\section{Data Collection}

Data was extracted from identified studies using a standardized form. The primary outcomes of interest were functional status (from asymptomatic and independent to dead, irrespective of the clinical scale used), and the incidence of cerebral infarction. Outcomes of secondary interest were the occurrence of DCI or symptomatic vasospasm in patients receiving any type of milrinone therapy prophylactically; serious side effects resulting from the intervention (arrhythmias, severe hypotension requiring discontinuation or increased vasopressor support, pulmonary edema, myocardial ischemia); surrogate measures of cerebral oxygen delivery; and reversal of angiographic vasospasm. Data extracted included patient population, patient characteristics, study design, description of measured outcomes, follow-up characteristics, statistical analysis used, and results reported for the outcomes of interest.

\section{Quality Assessment}

The quality of the body of evidence for the outcomes of interest across studies was rated by using the GRADE Working Group criteria. ${ }^{9-11}$ GRADE identifies 4 levels of evidence for quality assessment conducted in the context of a systematic review: high quality, moderate, low, and very low, based on how confident we are that the true effect lies close to the estimate of effect derived from the studies. The GRADE categories do not refer to individual studies, but to the body of evidence for each outcome.

\section{Results}

\section{Search Results}

We retrieved a total of 284 records from bibliographic databases after duplicate references were identified and removed (Figure 1). We eliminated 181 articles after screening their abstracts because they were unrelated to our search or because they were letters to the editor or editorial comments. We examined the full text of 103 studies and excluded another 79 because they were animal studies, practice surveys, review studies, or abstracts that were a repetition of other full text articles. We also eliminated 2 case series that were published in Japanese for which only a very short abstract was available. 24 studies featuring 957 patients were used to evaluate the evidence for the outcomes described above. 

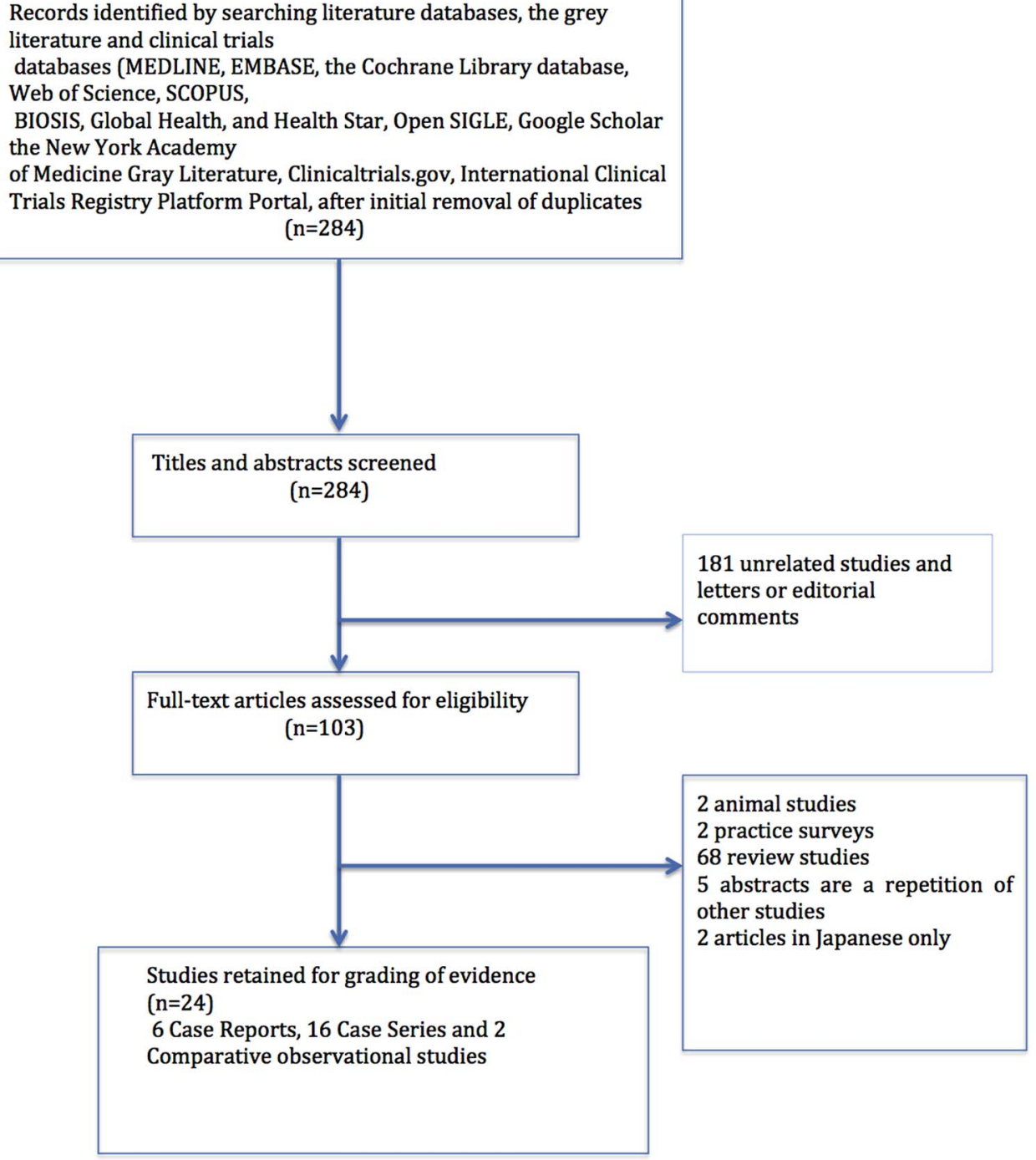

Figure 1: Flow diagram of search results

\section{Study Characteristics}

The 24 studies consisted of 9 abstracts ( 7 conference abstracts and 2 theses) and 15 full-text journal articles (Table 1).

There were 16 case series without a comparison group, 5 being prospectively acquired and 11 built from chart reviews. Moreover, 8 of those case series were published in abstract form only. The remaining citations consisted of 6 case reports, one prospective case series with a comparison group built with historical controls,${ }^{23}$ and one prospective non-randomized unblinded comparative study. ${ }^{12}$ In this latter study there is no mention of how the control group was selected and it is unclear whether allocation concealment was maintained. The primary outcome in this one study was the non-invasive measurement of transcranial mixed venous oxygen saturation during therapy. Other outcomes described in the methodology are cerebral perfusion pressure (CPP), dose of norepinephrine used, Glasgow Coma Scale, mean arterial pressure, markers of renal and liver function, and occurrence of vasospasm on computerized tomographic imaging with contrast. Although this study reports an increase in the cerebral oxygen saturation and an increase in CPP in the intervention group, these patients also received higher norepinephrine doses, and no statistical analysis attempting to control for this and other confounders is described.

All articles use adults with post aneurysmal subarachnoid hemorrhage except for one that investigates patients with traumatic subarachnoid hemorrhage. ${ }^{13}$ However, some include only patients with diagnosed angiographic or clinical vasospasm while others include only patients who did not yet develop vasospasm. The interventions are very heterogeneous and include intra-arterial milrinone combined or not with another intra-arterial vasodilator and followed or not by intravenous milrinone; continuous intra-arterial milrinone; cisternal milrinone irrigation; continuous intra-thecal lumbar milrinone; and continuous intravenous milrinone combined or not with vasopressor therapy. 
Table 1: Characteristics of milrinone studies. SAH: subarachnoid hemorrhage; WFNS: World Federation of Neurosurgical Societies scale; IA: intra-arterial; pts: patients; H\&H: Hunt and Hess scale. NA: not available

\begin{tabular}{|c|c|c|c|c|c|c|c|c|c|}
\hline Study & Design & $\begin{array}{l}\text { Publication } \\
\text { type }\end{array}$ & Study setting & $\begin{array}{c}\begin{array}{c}\text { Number } \\
\text { of } \\
\text { patients }\end{array} \\
\end{array}$ & Patients' characteristics & Disease severity & Intervention & Doses used & $\begin{array}{l}\text { Duration of } \\
\text { treatment }\end{array}$ \\
\hline $\begin{array}{l}\text { Yoshida et al. } \\
1997\end{array}$ & Case report & Journal article & Single center & 2 & $\begin{array}{l}\text { SAH with } \\
\text { symptomatic vasospasm }\end{array}$ & $\mathrm{H} \& \mathrm{H} 1$ and 3 & IA amrinone & 200 and $400 \mathrm{mg}$ & Single injections \\
\hline $\begin{array}{l}\text { Arakawa et al. } \\
2001\end{array}$ & $\begin{array}{l}\text { Prospective case } \\
\text { series }\end{array}$ & $\begin{array}{l}\text { Journal } \\
\text { article }\end{array}$ & $\begin{array}{l}\text { Single } \\
\text { center }\end{array}$ & 7 & $\begin{array}{l}\text { SAH with } \\
\text { symptomatic vasospasm }\end{array}$ & WFNS I-II & $\begin{array}{l}\text { IA milrinone + IV } \\
\text { infusion }\end{array}$ & $\begin{array}{l}\text { 5-15mg IA } \\
0.5-0.75 \mathrm{mcg} / \mathrm{kg} / \\
\text { min IV }\end{array}$ & Up to 2 weeks \\
\hline $\begin{array}{l}\text { Arakawa et al. } \\
2004\end{array}$ & $\begin{array}{l}\text { Prospective case } \\
\text { series with } \\
\text { historical controls }\end{array}$ & Journal article & Single center & 12 & $\mathrm{SAH}$ & WFNS IV-V & $\begin{array}{l}\text { Cisternal irrigation } \\
\text { with milrinone }\end{array}$ & $108 \mathrm{mcg} / \mathrm{h}$ & 11 to 18 days \\
\hline $\begin{array}{l}\text { Fraticelli et al. } \\
\quad 2008\end{array}$ & $\begin{array}{l}\text { Prospective case } \\
\text { series }\end{array}$ & Journal article & Single center & 22 & $\begin{array}{l}\text { SAH with } \\
\text { symptomatic vasospasm }\end{array}$ & WFNS I-IV & $\begin{array}{l}\text { IA milrinone + IV } \\
\text { infusion }\end{array}$ & $\begin{array}{l}8 \mathrm{mg} \mathrm{IA} ; 0.5-1.5 \mathrm{mcg} / \\
\mathrm{kg} / \mathrm{min} \text { IV }\end{array}$ & 14 days \\
\hline $\begin{array}{l}\text { Heintzelmann } \\
\quad 2009\end{array}$ & $\begin{array}{l}\text { Retrospective cases } \\
\text { series }\end{array}$ & Thesis & Single center & 30 & Angiographic vasospasm & NA & $\begin{array}{l}\text { IA milrinone + IV } \\
\text { infusion }\end{array}$ & NA & 14 days \\
\hline $\begin{array}{l}\text { Romero et al. } \\
2009\end{array}$ & $\begin{array}{l}\text { Prospective case } \\
\text { series }\end{array}$ & Journal article & Single center & 8 & $\begin{array}{l}\text { SAH with } \\
\text { symptomatic vasospasm }\end{array}$ & WFNS I-III & IA milrinone & $10-15 \mathrm{mg}$ & $\begin{array}{l}\text { Single injection } \\
\text { repeated once } \\
\text { PRN }\end{array}$ \\
\hline $\begin{array}{l}\text { Schmidt et al. } \\
2010\end{array}$ & $\begin{array}{l}\text { Retrospective case } \\
\text { series }\end{array}$ & Journal article & Single center & 73 & $\begin{array}{l}\text { SAH with } \\
\text { symptomatic vasospasm }\end{array}$ & $\begin{array}{l}\text { Moderate to severe } \\
\quad \text { radiographic } \\
\text { vasospasm } \\
(82 \%)\end{array}$ & $\begin{array}{l}\text { IA injection of } \\
\text { nicardipine } \mathrm{e} \pm \\
\text { milrinone }\end{array}$ & $10-17.5 \mathrm{mg}$ & Single injection \\
\hline Lecat 2011 & $\begin{array}{l}\text { Retrospective case } \\
\text { series }\end{array}$ & Thesis & Single center & 15 & $\begin{array}{l}\text { SAH with } \\
\text { symptomatic vasospasm }\end{array}$ & NA & $\begin{array}{l}\text { IA milrinone + IV } \\
\text { infusion }\end{array}$ & NA & NA \\
\hline $\begin{array}{l}\text { Shankar et al } \\
2011\end{array}$ & $\begin{array}{l}\text { Retrospective case } \\
\text { series }\end{array}$ & Journal article & Single center & 14 & $\begin{array}{l}\text { SAH with } \\
\text { symptomatic vasospasm }\end{array}$ & WFNS I-V & $\begin{array}{l}\text { IA milrinone + IV } \\
\text { infusion }\end{array}$ & $2.5-15 \mathrm{mg} \mathrm{IA}$ & NA \\
\hline $\begin{array}{l}\text { Mutoh et al } \\
2011\end{array}$ & $\begin{array}{l}\text { Prospective case } \\
\text { series }\end{array}$ & $\begin{array}{c}\text { Conference } \\
\text { abstract }\end{array}$ & $\begin{array}{l}\text { Single } \\
\text { center }\end{array}$ & 110 & $\begin{array}{l}\text { SAH with } \\
\text { symptomatic vasospasm }\end{array}$ & NA & Milrinone IV infusion & NA & NA \\
\hline $\begin{array}{l}\text { Lannes et al } \\
\quad 2012\end{array}$ & $\begin{array}{l}\text { Retrospective case } \\
\text { series }\end{array}$ & Journal article & Single center & 88 & $\begin{array}{l}\text { SAH with } \\
\text { symptomatic vasospasm }\end{array}$ & $\mathrm{H} \& \mathrm{H} 1-4$ & Milrinone IV infusion & $\begin{array}{l}01-0.2 \mathrm{mg} / \mathrm{kg} \text { bolus } \\
\mathrm{Up} \text { to } 1.25 \mathrm{mcg} / \\
\mathrm{kg} / \mathrm{min}\end{array}$ & $\begin{array}{l}\text { Mean duration } \\
9.8 \text { days }\end{array}$ \\
\hline $\begin{array}{l}\text { Elayoubi et al } \\
2013\end{array}$ & $\begin{array}{l}\text { Retrospective case } \\
\text { series }\end{array}$ & $\begin{array}{c}\text { Conference } \\
\text { abstract }\end{array}$ & Single center & 21 & $\begin{array}{l}\text { SAH with } \\
\text { symptomatic vasospasm }\end{array}$ & NA & IA milrinone & NA & Single injection \\
\hline
\end{tabular}


Table 1. Continued

\begin{tabular}{|c|c|c|c|c|c|c|c|c|c|}
\hline Study & Design & $\begin{array}{l}\text { Publication } \\
\text { type }\end{array}$ & Study setting & $\begin{array}{c}\text { Number } \\
\text { of } \\
\text { patients }\end{array}$ & Patients' characteristics & Disease severity & Intervention & Doses used & $\begin{array}{l}\text { Duration of } \\
\text { treatment }\end{array}$ \\
\hline Vas et al 2013 & $\begin{array}{l}\text { Retrospective case } \\
\text { series }\end{array}$ & $\begin{array}{c}\text { Conference } \\
\text { abstract }\end{array}$ & Single center & 5 & $\begin{array}{l}\text { SAH with Refractory } \\
\text { symptomatic vasospasm }\end{array}$ & NA & IA milrinone & NA & Single injections \\
\hline Lasry et al 2014 & Case report & Journal article & Single center & 2 & $\begin{array}{l}\text { Traumatic SAH with } \\
\text { symptomatic vasospasm }\end{array}$ & NA & IV milrinone infusion & $\begin{array}{l}0.1 \mathrm{mg} / \mathrm{kg} \text { bolus } \\
0.75 \mathrm{mcg} / \mathrm{kg} / \mathrm{min}\end{array}$ & 6 and 9 days \\
\hline $\begin{array}{l}\text { Ghanem et al } \\
2014\end{array}$ & $\begin{array}{l}\text { Comparative non- } \\
\text { randomized study }\end{array}$ & Journal article & Single center & 30 & SAH & WFNS I-III & $\begin{array}{l}\text { IV milrinone and } \\
\text { norepi vs norepi } \\
\text { alone }\end{array}$ & $\begin{array}{l}50 \mathrm{mcg} / \mathrm{kg} \text { bolus and } \\
0.5-0.75 \mathrm{mcg} / \\
\mathrm{kg} / \mathrm{min}\end{array}$ & 7 days \\
\hline $\begin{array}{l}\text { Anand et al } \\
2014\end{array}$ & Case report & Journal article & Single center & 1 & $\begin{array}{l}\text { SAH with refractory } \\
\text { vasospasm }\end{array}$ & $\begin{array}{c}\text { Severe diffuse } \\
\text { vasospasm }\end{array}$ & $\begin{array}{l}\text { Continuous IA } \\
\text { milrinone }\end{array}$ & $1 \mathrm{mg} / \mathrm{h}$ infusion & 72 hours \\
\hline $\begin{array}{l}\text { Zeiler et al } \\
2014\end{array}$ & Case report & Journal article & Single center & 2 & $\begin{array}{l}\text { SAH with symptomatic } \\
\text { vasospasm }\end{array}$ & $\mathrm{H} \& \mathrm{H} 2$ & IV milrinone & $\begin{array}{l}5 \mathrm{mg} \text { bolus } 1.5 \mathrm{mcg} / \\
\mathrm{kg} / \mathrm{min}\end{array}$ & 8 days in one patient \\
\hline $\begin{array}{l}\text { Sadamasa et al } \\
2014\end{array}$ & $\begin{array}{l}\text { Retrospective case } \\
\text { series }\end{array}$ & Journal article & Single center & 425 & SAH & WFNS I-V & $\begin{array}{l}\text { Cisternal and lumbar } \\
\text { intrathecal } \\
\text { milrinone }\end{array}$ & $\begin{array}{l}2.6 \mathrm{mg} / \text { day for lumbar } \\
\text { milrinone }\end{array}$ & $\begin{array}{l}\text { Until day } 14 \text { post } \\
\text { SAH }\end{array}$ \\
\hline $\begin{array}{l}\text { Sherif et al } \\
2015\end{array}$ & $\begin{array}{l}\text { Prospective cases } \\
\text { series }\end{array}$ & Journal article & Single center & 16 & $\begin{array}{l}\text { SAH with symptomatic } \\
\text { vasospasm }\end{array}$ & $\mathrm{H} \& \mathrm{H} 1-4$ & $\begin{array}{l}\text { IA milrinone } \\
\text { combined with IA } \\
\text { nimodipine } \\
\end{array}$ & $4-8 \mathrm{mg}$ & Single injections \\
\hline $\begin{array}{l}\text { Zeiler et al } \\
2015\end{array}$ & Case report & Journal article & Single center & 1 & $\begin{array}{l}\text { SAH with symptomatic } \\
\text { vasospasm }\end{array}$ & H\&H 4 WFNS IV & IV milrinone & $\begin{array}{l}5 \mathrm{mg} \text { bolus } \\
0.75 \mathrm{mcg} / \mathrm{kg} / \mathrm{min}\end{array}$ & 5 days \\
\hline $\begin{array}{l}\text { Osgood et al } \\
2015\end{array}$ & Case report & $\begin{array}{c}\text { Conference } \\
\text { abstract }\end{array}$ & Single center & 2 & $\begin{array}{l}\text { SAH with symptomatic } \\
\text { vasospasm }\end{array}$ & NA & Intrathecal milrinone & $0.87 \mathrm{mg}$ Q 8 hours & NA \\
\hline $\begin{array}{l}\text { Alamri et al } \\
2015\end{array}$ & $\begin{array}{l}\text { Retrospective case } \\
\text { series }\end{array}$ & $\begin{array}{c}\text { Conference } \\
\text { abstract }\end{array}$ & Single center & 17 & $\begin{array}{l}\text { SAH with refractory } \\
\text { vasospasm }\end{array}$ & $\begin{array}{l}\mathrm{H} \& \mathrm{H} 3 \text { (median } \\
\quad \text { score) }\end{array}$ & IA milrinone & $1-10 \mathrm{mg}$ & Single injections \\
\hline $\begin{array}{l}\text { Thaher et al } \\
2015\end{array}$ & $\begin{array}{l}\text { Retrospective case } \\
\text { series }\end{array}$ & $\begin{array}{c}\text { Conference } \\
\text { abstract }\end{array}$ & Single center & 36 & $\begin{array}{l}\text { SAH with symptomatic } \\
\text { vasospasm }\end{array}$ & NA & IA milrinone & $8 \mathrm{mg}$ & Single injection \\
\hline $\begin{array}{l}\text { Alamri et al } \\
2016\end{array}$ & $\begin{array}{l}\text { Retrospective case } \\
\text { series }\end{array}$ & $\begin{array}{c}\text { Conference } \\
\text { abstract }\end{array}$ & Single center & 18 & $\begin{array}{l}\text { SAH with refractory } \\
\text { vasospasm }\end{array}$ & NA & IV milrinone & $\begin{array}{l}8 \mathrm{mg} \text { bolus }+ \text { up } \\
2.75 \mathrm{mcg} / \mathrm{kg} / \mathrm{min}\end{array}$ & NA \\
\hline
\end{tabular}


Measured outcomes and follow-up times were also very diverse: angiographic response, ${ }^{14-21}$ Neurological exam, ${ }^{13,17,22-26}$ Glasgow Outcome scale (GOS), ${ }^{27}$ modified Rankin Scale $(\mathrm{mRS}),{ }^{18,20,21,28-33}$ cerebral infarction, ${ }^{31}$ Barthel index, ${ }^{28}$ and TCD values. ${ }^{34,35}$ In 7 studies only data on immediate results were available, ${ }^{14,15,17,19,23,34,35}$ and in one publication the follow-up time was not specified. ${ }^{24}$ All reviewed articles except for $7^{17,19,20,23-25,35}$ reported information on the occurrence of adverse effects associated with milrinone: 12 of the 17 studies reported that no adverse hemodynamic changes were observed $^{13,14,21,22,26,27,29-34}$ while the other $5^{12,15,16,18,28}$ reported only mild increases in heart rate and a decreased blood pressure that in some cases required institution of vasopressors or an increase in the dose of preexisting vasopressors. No instances of severe hypotension requiring discontinuation of therapy or severe arrhythmias or other significant side effects were described.

Using the Clinicaltrials.gov database we were able to identify one registered randomized single-center double blind control trial of the use of milrinone to treat delayed cerebral ischemia in patients with subarachnoid hemorrhage. Patients in the intervention group will receive intravenous milrinone in addition to standard hyperdynamic therapy, while the control group will receive placebo plus standard therapy (https://clinicaltrials.gov/ct2/ show/NCT02712788?term=milrinone+AND+vasospasm\&rank= 1+AND+vasospasm\&rank=1). Starting date was April 2016.

\section{Outcome Measures and Quality rating}

In the GRADE approach to rating the quality of the evidence available one must define which outcomes are relevant for the specific question that guides a systematic review. This is an "outcome centric" approach, where the quality of the evidence is evaluated for each outcome across different studies. ${ }^{9,10}$ The present question is "does the use of milrinone to treat patients with symptomatic vasospasm or delayed cerebral ischemia improve outcomes when compared to current standard therapy?" Outcomes may be clinical (e.g. neurological function), physiological (e.g. cerebral blood flow), societal (e.g. shortened hospital stay), or negative (e.g. adverse events, costs). These outcomes are then ranked by their impact on clinical decision making as critical, important, or unimportant. The quality assessment of the evidence for important outcomes can then be used by guideline panels that will formulate practice recommendations.

A multidisciplinary research group recommended that observational studies and clinical trials investigating new therapies for patients with SAH should use, as main outcomes, only patient functional neurological status and cerebral infarction identified on CT, MRI or autopsy after exclusion of procedure-related ischemic lesions. ${ }^{36}$ Clinical deterioration due to DCI should be a secondary outcome measure, and cerebral vasospasm identified on angiogram or TCD, if used as an outcome at all, should be interpreted in conjunction with DCI. This recommendation was also emphasized in a 2011 multidisciplinary consensus conference. ${ }^{37}$ Table 2 summarizes the outcomes and follow-up times for the included studies.

\section{Functional Status}

Functional neurological status can be ascertained by means of established scales (mRS, GOS) or by detailed follow-up neurological examination (usually at 3 and 6 months), and is usually described as "good" or "bad." A total of 9 studies including
632 patients reported mRS scores ${ }^{18,20-21,28-33}$ and GOS scores ${ }^{14,27}$ in patients with DCI treated with milrinone, with follow-up times that varied from "at discharge" to a mean of 44.6 months. Good outcomes ( $\mathrm{mRS} \leq 2$ or GOS $\geq 4$ ) were seen in $57-82 \%$ of patients. One article ${ }^{20}$ reported $80 \%$ good outcomes, but included patients with a mRS $\leq 3$. The case reports also describe good outcomes, but with very small numbers and in less descriptive terms. These results are better than what has been usually reported in the literature describing usual care with hypertensive or triple $\mathrm{H}$ therapy. ${ }^{38,39}$ However, because of the absence of a comparison group, this collection of case series constitutes only a very low quality of evidence for this outcome.

\section{Cerebral Infarction}

Cerebral infarction associated with DCI and not caused by parenchymal hematoma or procedures such as clipping, coiling or insertion of external ventricular drains is another important outcome that generally correlates with functional neurological status. ${ }^{36}$ In one study reviewing only patients who had developed delayed neurological deficits associated with radiological vasospasm (total sample 88) the proportion of patients with new ischemic lesions on CT not associated with procedures was of $36.4 \% .^{30}$ The only other study that described this outcome used a combination of cisternal and lumbar irrigation with a solution containing milrinone. ${ }^{31}$ The subjects were patients with $\mathrm{SAH}$, both with and without DCI; 7.1\% developed cerebral infarction. The difference in treatment approach and the study design make it impossible to determine the significance of these results and their association with the milrinone therapy.

\section{Angiographic Response}

We identified 12 studies, containing 191 patients, that described the use of intra-arterial milrinone and measured the change in vessel caliber as an outcome. There was a high degree of heterogeneity regarding the intervention. Some studies used only intraarterial milrinone while others used a combination of papaverine followed by milrinone, ${ }^{14}$ nicardipine combined or not with milrinone,${ }^{16}$ nimodipine followed by milrinone, ${ }^{21}$ and intra-arterial amrinone. $^{22}$

Changes in vessel diameter were analyzed as "before and after." Only one retrospective observational study had a comparison group. ${ }^{19}$ The study targeted arteries, but the allocation to the intervention was not through randomization, and the control group included vessels that had no vasospasm. All articles observed an improvement in vessel caliber in most or all arteries studied, varying from "mild" to "excellent." In the study with a comparison group $90 \%$ of vessels treated with milrinone had improved diameter compared to $11 \%$ in the control group. There is no data to suggest that immediate changes in vessel caliber correlate with long term outcome.

\section{Symptomatic Vasospasm or Delayed Ischemic Neurologic Deficits}

There are several problems in using the occurrence of ischemic events as an outcome, due to wide variations in its definition, and in the use of radiological means to corroborate its presence because it is a diagnosis of exclusion. For this reason, it is difficult to compare results across studies and to reliably evaluate whether 
Table 2: Outcomes and follow-up times. AEs adverse effects; VSP vasospasm; mRS modified Rankin scale; HR heart rate; BP blood pressure; NR not reported; CO cardiac output; rSO2 regional cerebral oxygen saturation; DIND delayed ischemic neurologic deficit; TCD transcranial doppler.

\begin{tabular}{|c|c|c|c|}
\hline Study & Outcomes & AEs milrinone & Follow-up \\
\hline Yoshida 1997 & Neurological examination & None & $\begin{array}{l}2 \text { months } \\
1 \text { year }\end{array}$ \\
\hline Arakawa 2001 & $\begin{array}{l}\text { Glasgow Outcome score } \\
\text { Angiographic response }\end{array}$ & No hemodynamic changes & Immediate results \\
\hline Arakawa 2004 & Glasgow Outcome Scale Occurrence symptomatic VSP & No hemodynamic changes & 3 months \\
\hline Fraticelli 2008 & $\mathrm{mRS}$ and Barthel index, angiographic response & Mild increase in HR; need for pressors & 12 and 18 months \\
\hline Heintzelmann 2009 & Angiographic change & Mild increase in HR & Immediate results \\
\hline Romero 2009 & $\mathrm{mRS}$ and Barthel index angiographic response & No hemodynamic changes & 3 months \\
\hline Schmidt 2010 & $\begin{array}{l}\text { Angiographic change, need for vasopressors, surrogates for organ ischemia, } \\
\text { 30-day in-hospital mortality and disposition at discharge }\end{array}$ & Decreased BP, higher vasopressor dose & $\begin{array}{l}30 \text { days } \\
\text { Discharge }\end{array}$ \\
\hline Lecat 2011 & Neurological examination, Angiographic change & NR & Immediate results \\
\hline Shankar 2011 & Angiographic response, $\mathrm{mRS}$ & Mild hypotension not treated & Immediate and at discharge \\
\hline Mutoh 2011 & $\mathrm{CO}$, changes in $\mathrm{rSO} 2$, neurological examination & NR & Immediate \\
\hline Lannes 2012 & mRS Cerebral infarction & None & Mean $=44.6$ months \\
\hline Elayoubi 2013 & Angiographic response & NR & Immediate response \\
\hline Lasry 2014 & Neurological examination & None & At discharge \\
\hline Vas 2013 & Angiographic response, $\mathrm{mRS}$ & NR & I6-12 months \\
\hline Ghanem 2014 & Changes in rSO2, occurrence angio spasm & higher vasopressor dose & 1 week \\
\hline Anand 2014 & Neurological examination & $\mathrm{NR}$ & Not reported \\
\hline Zeiler 2014 & Neurological examination & $\mathrm{NR}$ & Days 22 and 25 \\
\hline Sadamasa 2014 & DIND, infarction, mRS at 3 months & None & 3 months \\
\hline Sherif 2015 & Angiographic response, TCD, mRS & None & 4.5 months (mean) \\
\hline Zeiler 2015 & Neurological examination & None & Discharge to ward \\
\hline Osgood 2015 & TCD, angiographic appearance & None & Immediate effect \\
\hline Alamri 2015 & Median mRS & None & At discharge and at 3 months \\
\hline Thaher 2015 & TCD and brain tissue oxygenation & NR & Immediate response \\
\hline Alamri 2016 & mRS on discharge & None & At discharge \\
\hline
\end{tabular}

the ascertainment of its frequency has been unbiased. Only two studies described this outcome and the occurrence of "symptomatic vasospasm" varied from 16 to $25 \%$ of treated patients. ${ }^{27,23}$

\section{Adverse Effects of Milrinone/Amrinone}

The presence of adverse effects is an important outcome, particularly because most studies used doses of milrinone that are well above those recommended in the treatment of heart failure $(50 \mathrm{mcg} / \mathrm{kg}$ IV bolus and maintenance of $0.125-0.75 \mathrm{mcg} / \mathrm{kg} / \mathrm{min}$ for milrinone; $750 \mathrm{mcg} / \mathrm{kg}$ IV bolus for amrinone). In $12 \mathrm{pub}-$ lications with a total sample of 288 patients, doses up to $400 \mathrm{mg}$ intra-arterially for amrinone and up to $15 \mathrm{mg}$ intra-arterially and $0.2 \mathrm{mg} / \mathrm{kg}$ intravenously of milrinone were used. ${ }^{13,14,16,18,22,28-30}$ In 8 of those, no hemodynamic changes were observed, while in the other 4 the authors describe only mild tachycardia or a decrease in blood pressure that did not need to be treated or that required the institution or the increase in the dose of vasopressors to maintain the mean arterial pressure at pre-specified levels. No patients developed severe adverse effects such as severe hypotension requiring the discontinuation of therapy or ventricular and supraventricular arrhythmias. This excellent safety profile occurred despite the fact that in two studies milrinone was given in combination with another vasodilator, either nicardipine or nimodipine. ${ }^{16,21}$ One must, however, keep in mind the heterogeneity of the studies and the mostly retrospective design of the data acquisition.

\section{Discussion}

Until recently the suggested approach to treating episodes of DCI following subarachnoid hemorrhage was based on the induction of varying degrees of hypertension, hypervolemia and hemodilutionthe so-called triple- $\mathrm{H}$ therapy-in an effort to increase perfusion to ischemic areas of the brain. The American Heart Association (AHA) Guidelines for the management of aneurysmal SAH published in 2009 still stated that "volume expansion, induction of hypertension and hemodilution (triple-H therapy)" was a reasonable approach. ${ }^{40}$ This recommendation, however, was based on scant evidence, and there were no controlled randomized trials to support it. Furthermore, the hypervolemia and hemodilution components do not appear to offer any additional benefits to induced hypertension 
alone. ${ }^{41-43}$ In the 2012 revision of the same guidelines, only euvolemia and induction of hypertension are recommended. ${ }^{44}$ Consistent with these findings, a Neurocritical Care Society multidisciplinary consensus conference from 2011 recommended to treat DCI following SAH with euvolemia, stepwise increase in MAP titrated to effect, and inotropic therapy if no clinical improvement was seen with blood pressure augmentation. ${ }^{37}$ Endovascular therapies with intra-arterial vasodilators and/or angioplasty were recommended in cases that remained refractory to medical treatment. The authors of these guidelines make it clear in their review of the subject that there is a disturbing dearth of high-quality data to support their recommendations.

Despite a thorough search with no limitations of language (both Japanese articles were case series) and the inclusion of the grey literature databases, conference abstracts and trials databases, we were unable to identify any randomized controlled trials of the use of milrinone or amrinone in the management of patients with subarachnoid hemorrhage. Only case reports, case series, and two non-randomized comparative studies were found. There were differences in the study populations as well: some included SAH patients without vasospasm and others only SAH patients who had already developed delayed cerebral ischemia either untreated or refractory to initial therapy. Treatment protocols were also quite different in their duration, manner of administration (intraarterial, intravenously, cisternal, lumbar), and adjunct therapy. One comparative study used arteries as study targets and the other had a surrogate measure of cerebral oxygen delivery as its main outcome, and a short follow-up time.

The results in these series appear encouraging, with functional neurological outcomes that are better than those traditionally cited in the literature. Of particular interest is the apparent lack of observed side effects, even with the high doses used in most studies. Furthermore, the serious side effects frequently associated with traditional therapy, such as pulmonary edema and myocardial ischemia, could potentially be obviated if the main treatment goals were not guided chiefly by augmentation therapy with vasopressors and fluids.

An obvious limitation of our study, however, is the absence of randomized control trials and the wide variation in regimens used. The exclusion of the two articles written in Japanese with only very short abstracts is another limitation, but the final rating of the evidence would not have changed since both were case series. Even if from a physiological point of view milrinone appears as a possible therapeutic choice in the treatment of DCI, its expanding use has not been followed by well-designed trials to corroborate its efficacy. This carries the risk of an intervention becoming so deeply rooted in an institution's practice that it becomes very difficult to perform a randomized study. Physicians may become so convinced of its efficacy that they refuse to enroll their patients, fearing they may be allocated to a treatment that they consider less beneficial.

\section{Conclusion}

Since the first reports of its use to treat patients with DCI secondary to SAH in the late 1990 s and early $2000 \mathrm{~s},{ }^{14,22}$ milrinone has been included as a therapeutic option using different protocols in several hospitals across the world. ${ }^{7}$ However, in this systematic review and using the GRADE system we determined that there is currently only very low quality evidence to support an effect on important outcomes such as functional neurological status and the incidence of cerebral infarction and adverse effects.
The same applies to physiological outcomes such as angiographic response and changes in cerebral oxymetry. Because of the expanding use of milrinone to treat delayed cerebral ischemia in patients with subarachnoid hemorrhage, there is an urgent need for a randomized control trial investigating its effects on clinically relevant outcomes.

\section{Disclosures}

The authors do not have any competing interests to disclose. All authors have completed the Unified Competing interest form. This study was supported by personal funds.

\section{ACKNOWLEDGEMENTS}

We wish to acknowledge the invaluable work of Ms. Bénédicte Nauche MBSI / MLIS,

Librarian at the McGill University Health Centre Library, in developing the search strategy and in analyzing its results.

\section{REFERENCES}

1. Dorsch N. A clinical review of cerebral vasospasm and delayed ischaemia following neurysm rupture. Acta Neurochir Suppl. 2011;110(Pt 1):5-6.

2. Fergusen S, Macdonald RL. Predictors of cerebral infarction in patients with aneurysmal subarachnoid hemorrhage. Neurosurgery. 2007;60(4):658-67.

3. Proust F, Hannequin D, Langlois O, Freger P, Creissard P. Causes of morbidity and mortality after ruptured aneurysm surgery in a series of 230 patients. The importance of control angiography. Stroke. 1995;26(9):1553-7.

4. Findlay JM, Nisar J, Darsaut T. Cerebral Vasospasm: A Review. Can J Neurol Sci. 2016;43(1):15-32.

5. Rybalkin SD, Yan C, Bornfeldt KE, Beavo JA. Cyclic GMP phosphodiesterases and regulation of smooth muscle function. Circ Res. 2003;93(4):280-91.

6. Schoch B, Regel JP, Wichert M, Gasser T, Volbracht L, Stolke D. Analysis of intrathecal interleukin-6 as a potential predictive factor for vasospasm in subarachnoid hemorrhage. Neurosurgery. 2007;60(5):828-36.

7. Velly LJ, Bilotta F, Fabregas N, Soehle M, Bruder NJ, Nathanson $\mathrm{MH}$, et al. Anaesthetic and ICU management of aneurysmal subarachnoid haemorrhage: a survey of European practice. Eur J Anaesthesiol. 2015;32(3):168-76.

8. Liberati A, Altman DG, Tetzlaff J, Mulrow C, Gotzsche PC, Ioannidis JP, et al. The PRISMA statement for reporting systematic reviews and meta-analyses of studies that evaluate health care interventions: explanation and elaboration. PLoS medicine. 2009;6(7):e1000100.

9. Guyatt GH, Oxman AD, Vist GE, Kunz R, Falck-Ytter Y, Alonso-Coello P, et al. GRADE: an emerging consensus on rating quality of evidence and strength of recommendations. Bmj. 2008; 336(7650):924-6.

10. Guyatt G, Oxman AD, Akl EA, Kunz R, Vist G, Brozek J, et al. GRADE guidelines: 1 . Introduction-GRADE evidence profiles and summary of findings tables. J Clin Epidemiol. 2011;64(4):383-394.

11. Balshem H, Helfand M, Schunemann HJ, Oxman AD, Kunz R, Brozek J, et al. GRADE guidelines: 3 . Rating the quality of evidence. J Clin Epidemiol. 2011;64(4):401-6.

12. Ghanem MA, Shabana AM. Effects of Milrinone continuous intravenous infusion on global cerebral oxygenation and cerebral vasospasm after cerebral aneurysm surgical clipping. Egyptian Journal of Anaesthesia. 2014;30(1):73-82.

13. Lasry $\mathrm{O}$, Marcoux J. The use of intravenous Milrinone to treat cerebral vasospasm following traumatic subarachnoid hemorrhage. Springerplus. 2014;3(1):633.

14. Arakawa Y, Kikuta K, Hojo M, Goto Y, Ishii A, Yamagata S. Milrinone for the treatment of cerebral vasospasm after 
subarachnoid hemorrhage: report of seven cases. Neurosurgery. 2001;48(4):723-8; discussion 8-30.

15. Heintzelmann M. Efficacité de la Milrinone intra-artérielle dans le traitement du vasospasme cérébral secondaire à une hémorragie méningée: Université Joseph Fourier, Grenoble; 2009.

16. Schmidt U, Bittner E, Pivi S, Marota JJA. Hemodynamic management and outcome of patients treated for cerebral vasospasm with intraarterial nicardipine and/or milrinone. Anesthesia and Analgesia. 2010;110(3):895-902.

17. Lecat B. Intérêt de la milrinone intra-artérielle dans le traitement curatif du vasospasme cérébral après hémorragie méningée par rupture anevrysmale Université de Picardie; 2011.

18. Shankar JJ, dos Santos MP, Deus-Silva L, Lum C. Angiographic evaluation of the effect of intra-arterial milrinone therapy in patients with vasospasm from aneurysmal subarachnoid hemorrhage. Neuroradiology. 2011;53(2):123-8.

19. Elayoubi K, Lancu-Gontard D, Nguyen T, Guilbert F, Raymond J, Roy D, et al. Angiographic outcome of intra-arterial milrinone on cerebral vasospasm after subarachnoid haemorrhage. Canadian Journal of Neurological Sciences Conference: 48th Annual Congress of the Canadian Neurological Sciences Federation Montreal, QC Canada Conference Start. 2013;40(3 SUPPL. 1).

20. Vas NO, Beigh SA, Alabdulraheem NS, Bosnjakovic P, Abulhasan YB. Targeted intra-arterial milrinone for the treatment of symptomatic cerebral vasospasm in aneurysmal sah. Neurocritical Care. 2013;1:S271.

21. Sherif C, Wambacher B, Loyoddin M, Karaic R, Krafft P, Valentin A, et al. Repeated combined endovascular therapy with milrinone and nimodipine for the treatment of severe vasospasm: preliminary results. Acta Neurochir Suppl. 2 2015;120:203-7.

22. Yoshida K, Watanabe $\mathrm{H}$, Nakamura S. Intraarterial injection of amrinone for vasospasm induced by subarachnoid hemorrhage. Ajnr: American Journal of Neuroradiology. 1997;18(3):492-6.

23. Mutoh T, Kobayashi S, Kazumata K, Ishikawa T, Suzuki A. Dobutamine versus mirlinone for intensive hyperdynamic therapy to relieve focal cerebral ischemia caused by vasospasm after subarachnoid hemorrhage. Circulation. 2011;1.

24. Anand S, Goel G, Gupta V. Continuous intra-arterial dilatation with nimodipine and milrinone for refractory cerebral vasospasm. Journal of Neurosurgical Anesthesiology. 2014;26(1):92-3.

25. Zeiler FA, Silvaggio J, Kaufmann AM, Gillman LM, West M. Norepinephrine as a potential aggravator of symptomatic cerebral vasospasm: two cases and argument for milrinone therapy. case report. 2015;2014:630970.

26. Zeiler FA, Silvaggio J. Early Angiographic Resolution of Cerebral Vasospasm with High Dose Intravenous Milrinone Therapy. case report. 2015;2015:164597.

27. Arakawa Y, Kikuta K, Hojo M, Goto Y, Yamagata S, Nozaki K, et al. Milrinone reduces cerebral vasospasm after subarachnoid hemorrhage of WFNS grade IV or V. Neurologia MedicoChirurgica. 2004;44(8):393-400; discussion 1.

28. Fraticelli AT, Cholley BP, Losser MR, Saint Maurice JP, Payen D. Milrinone for the treatment of cerebral vasospasm after aneurysmal subarachnoid hemorrhage. Stroke. 2008;39(3):893-8.

29. Romero CM, Morales D, Reccius A, Mena F, Prieto J, Bustos P, et al. Milrinone as a rescue therapy for symptomatic refractory cerebral vasospasm in aneurysmal subarachnoid hemorrhage. Neurocritical Care. 2009;11(2):165-71.

30. Lannes M, Teitelbaum J, del Pilar Cortes M, Cardoso M, Angle M. Milrinone and homeostasis to treat cerebral vasospasm associated with subarachnoid hemorrhage: the Montreal Neurological Hospital protocol. Neurocritical Care. 2012;16(3):354-62.

31. Sadamasa N, Yoshida K, Narumi O, Chin M, Yamagata S. Milrinone via lumbar subarachnoid catheter for vasospasm after aneurysmal subarachnoid hemorrhage. Neurocritical Care. 2014;21(3):470-5.

32. Alamri AS, Angle MR, Tampieri D, Perez A, Lo BWY, Teitelbaum JS. Benefit of intra-arterial milrinone in subarachnoid hemorrhage with refractory vasospasm. Neurocritical Care. 2015;1:S198.

33. Alamri AS, Alturki A, Badawy M, Letourneau J, Lannes M, Angle M, et al. Safety and outcome of high doses IV milirinone in subarachnoid hemorrhage with refractory vasospasm. Stroke Conference: American Heart Association/American Stroke Association. 2016;47(no pagination).

34. Osgood ML, Brogan M, Ahrens C, Rasmussen P, Dani D. Intrathecal milrinone for the treatment of refractory cerebral vasospasm in aneurysmal subarachnoid hemorrhage: Report of 2 patients. Neurocritical Care. 2015;1:S230.

35. Thaher F, Hickmann A, Aguilar M, Martinez R, Danassis D, Kurre W, et al. Short-term intraarterial Milrinone infusion for the treatment of posthemorrhagic Basospasm. Interventional Neuroradiology. 2015;21:176.

36. Vergouwen MD, Vermeulen M, van Gijn J, Rinkel GJ, Wijdicks EF, Muizelaar JP, et al. Definition of delayed cerebral ischemia after aneurysmal subarachnoid hemorrhage as an outcome event in clinical trials and observational studies: proposal of a multidisciplinary research group. Stroke. 2010;41(10):2391-5.

37. Diringer MN, Bleck TP, Hemphill IJC, Menon D, Shutter L, Vespa $\mathrm{P}$, et al. Critical care management of patients following aneurysmal subarachnoid hemorrhage: Recommendations from the neurocritical care society's multidisciplinary consensus conference. Neurocritical Care. 2011;15(2):211-40.

38. Quinn A C IK, Sharma A, Beecroft L, Geldard J, Thomson S, Hensor E, Tennant A, Ross S. Sex and cerebral vasospasm in Yorkshire, UK. In Macdonald RL ed Cerebral vasospasm: advances in research and treatment. International Conference on Cerebral Vasospasm (8th: 2003: Chicago, Ill.). New York: New York; 2005. p. 189-93

39. Lovelock CE, Rinkel GJ, Rothwell PM. Time trends in outcome of subarachnoid hemorrhage: Population-based study and systematic review. Neurology. 2010;74(19):1494-501.

40. Bederson JB, Connolly ES Jr, Batjer HH, Dacey RG, Dion JE, Diringer MN, et al. Guidelines for the management of aneurysmal subarachnoid hemorrhage: a statement for healthcare professionals from a special writing group of the Stroke Council, American Heart Association. Stroke. 2009;40(3):994-1025.

41. Lennihan L MS, Fink ME, Beckford A, Paik MC, Zhang H, et al. Effect of hypervolemic therapy on cerebral blood flow after subarachnoid hemorrhage : A randomized controlled trial. Stroke. 2000;31(2):383-91.

42. Rinkel GJ, Feigin VL, Algra A, van Gijn J. Circulatory volume expansion therapy for aneurysmal subarachnoid haemorrhage. The Cochrane database of systematic reviews. 2004(4):CD000483.

43. Dankbaar JW, Slooter AJ, Rinkel GJ, Schaaf IC. Effect of different components of triple-H therapy on cerebral perfusion in patients with aneurysmal subarachnoid haemorrhage: a systematic review. Critical care. 2010;14(1):R23.

44. Connolly ES Jr, Rabinstein AA, Carhuapoma JR, Derdeyn CP, Dion J, Higashida RT, et al. Guidelines for the management of aneurysmal subarachnoid hemorrhage: a guideline for healthcare professionals from the American Heart Association/american Stroke Association. Stroke. 2012;43(6):1711-37. 